\title{
Entre regulações e táticas: músicas nas ruas da cidade do Rio de Janeiro
}

\section{Between regulations and tactics: music in the streets of Rio de Janeiro}

\section{Jhessica Reia}

Centro de Tecnologia e Sociedade da Fundação Getulio Vargas DIREITO RIO (CTS-FGV). Rio de janeiro, RJ, Brasil ORCID: 0000-0002-6023-4584

$<$ jheleiosa@gmail.com>

\section{Micael Herschmann}

Escola de Comunicação (ECO) - Programa de Pós-Graduação em Comunicação da Universidade Federal do Rio de Janeiro (PPGCOM-UFRJ). Rio de Janeiro, RJ, Brasil ORCID: 0000-0001-8859-0671 $<$ micaelmh@globo.com>

\author{
Cíntia S. Fernandes \\ Programa de Pós-Graduação em \\ Comunicação da Universidade do Estado \\ do Rio de Janeiro (PPGCOM-UERJ). Rio \\ de Janeiro, RJ, Brasil \\ ORCID: 0000-0002-7501-6387 \\ <cintia@lagoadaconceicao.com>
}

\section{Como citar este artigo (How to cite this article): \\ REIA, J.; HERSCHMANN, M.; FERNANDES, C. S. - Entre regulações e táticas: músicas nas ruas da cidade do Rio de Janeiro. Revista Famecos, Porto Alegre, v. 25, n. 3, p. 1-23, setembro, outubro, novembro e dezembro de 2018: ID30608. DOI: http://dx.doi.org/10.15448/1980-3729.2018.3.30608.}

\section{RESUMO}

Algumas práticas culturais que ocorrem nos espaços públicos urbanos evidenciam disputas pelo direito à cidade, justamente por apontarem para dinâmicas de poder e resistências que ocorrem nas cidades contemporâneas. Adotando uma perspectiva que conjuga comunicação, cidade e música, este trabalho tem como objetivo central analisar as dinâmicas entre regulação e táticas da música nas ruas do Rio de Janeiro em um contexto de megaeventos e transição política e econômica. A análise construída aqui busca compreender os processos de ocupação e mobilização política que gravitam em torno da música tocada nas ruas cariocas. Estas reflexões tomaram como referência entrevistas que foram realizadas com artistas, produtores culturais, lideranças locais e autoridades, assim como observação participante que ocorreram entre 2013 e 2017.

\section{ABSTRACT}

Some of the cultural practices taking place in urban public spaces can highlight disputes over the right to the city, precisely because they shed light on dynamics of power and resistance in contemporary cities. By adopting a perspective that combines communication studies, city and music, this work aims to analyze the dynamics between regulations and tactics employed by musicians performing in the streets of Rio de Janeiro, in a context of megaevents, as well as political and economic crisis. The study also attempts to understand the processes of occupation and political mobilization related to the music performed in the streets of Rio. It draws from in-depth interviews with artists, cultural producers, local leaders, and authorities, as well as participant observation carried out between 2013 and 2017.

\section{Introdução}

No momento em que o livro de Lefebvre (1968) Le Droit à la Ville, que trouxe à tona a discussão sobre o direito à cidade, completa 50 anos, olhar para a "apresentação" das cidades é um exercício cada vez mais necessário. 0 campo da comunicação tem se destacado através de abordagens que analisam as cidades a partir de suas relações com mídias, mediações, práticas culturais e 
diversos outros processos comunicacionais. Pode-se considerar, por exemplo, o conceito de "cidade informacional" de Castells (1989), as "cidades midiáticas" de McQuire (2006; 2008) e o aumento do interesse pelas "cidades inteligentes" na literatura acadêmica e nos processos de formulação e implementação de políticas públicas (Kitchin, 2014; Santaella, 2016; Lemos, Mont'alverne, 2015). Contudo, é necessário reconhecer uma história mais antiga da produção mediada do espaço urbano do que aquela concentrada nas novas tecnologias da comunicação e da informação, bem como nem sempre a relação entre mídia e espaço é óbvia ou visível.

A proposta de se pensar o espaço urbano enquanto espaço comunicativo para além dos meios de comunicação de massa e das novas tecnologias permite explorar outras relações entre estruturas e mediações. Na análise apresentada por Shannon Mattern (2015) propõe-se uma "arqueologia da mídia urbana" - em referência à Kittler e Griffin (1996), que desenvolveram a ideia da "cidade como meio",permeadaporredesdeinformação-quebusqueem profundidadeahistória material da cidade, para além dos dispositivos e de encontro às redes e ondas que constituem (e sempre constituíram) as cidades. Mattern $(2015 ; 2017)$ também afirma que os espaços urbanos têm sido "inteligentes" e mediados por milhares de anos, ao analisar as redes e estruturas (físicas e simbólicas) que as compõem.

Não menos importante para esta discussão é a perspectiva de Georgiou (2013), cujo trabalho colabora para o entendimento de que grande parte do que sabemos sobre as cidades é mediado por representações e práticas comunicacionais. As cidades seriam, então, constantemente reconstruídas e ressignificadas através de variadas formas de comunicação entre os indivíduos, e entre eles e o espaço urbano midiatizado e mediado. Morley (2009) ressalta a importância de se pensar as relações entre cidade e processos comunicacionais de maneira não centrada apenas em mídia e que articulem diversas redes de comunicação, transporte e pessoas. Neste contexto, o desenvolvimento de trabalhos que se ligam ao conceito de "comunicação urbana" vem se consolidando ao apresentarem abordagens interdisciplinares e outros pontos de vista sobre comunicação e cidades'.

A partir dessa perspectiva, que entende os processos comunicacionais de maneira mais ampla dentro da comunicação, é possível analisar performances musicais que acontecem nas ruas como práticas de diálogo e comunicação entre

1 Ver, por exemplo, a edição especial da revista International Journal of Communication, organizada por Giorgia Aiello e Simone Tosoni (2016). Ver também as coletâneas do Urban Communication Reader, em dois volumes: Burd e outros (2007); Jassem e outros (2010). Segundo Aiello e Tosoni (2016), a comunicação urbana se dedica a estudar as formas pelas quais as pessoas se conectam (ou não se conectam) com os outros e com o espaço urbano através de meios simbólicos, tecnológicos e/ou materiais. 
atores e audiência, assim como entre estes e o espaço urbano, capaz de engajar, incomodar e cativar aqueles quem passam pelas performances que acontecem nos espaços públicos. A música nas ruas pode transmitir mensagens e gerar interação, transformando temporariamente a percepção do espaço público no qual ela ocorre, interagindo com os sentidos humanos (Attali, 2009; Picker, 2003; Urry, 2003), e sendo, portanto, uma prática comunicacional que ajuda a conectar as pessoas umas às outras e ao próprio ambiente urbano (Aiello, Tosoni, 2016).

Assim, múltiplas abordagens, que tecem sentidos dos usos e apropriações das cidades contemporâneas, têm se aproximado do conceito de direito à cidade que, desde seu aparecimento décadas atrás, vem sendo ampliado e incorporado em políticas públicas. A perspectiva de uma cidade que deva acolher a diversidade, que permita uma experiência cidadã baseada em múltiplas práticas socioculturais, exacerba-se nas disputas pelos espaços públicos urbanos. Ainda que, atualmente, não exista uma definição única e simples de "espaço público"2 (que vai além da simples oposição ao "espaço privado") ${ }^{3}$, há uma literatura que aponta para a importância de reflexões sobre as transformações desses espaços, uma vez que ruas, avenidas, calçadas e praças podem ter seus usos modificados e ressignificados ao longo das décadas (Loukaitou-Sideris, Ehrenfeucht, 2009).

Algumas práticas e manifestações culturais que ocorrem nos espaços públicos evidenciam disputas pelo direito à cidade, justamente por apontarem para dinâmicas de poder e controle desses espaços. O caso que será brevemente analisado aqui é o da música nas ruas do Rio de Janeiro, que engloba tanto o que comumente se identifica como música de rua (aquela que é pensada especificamente para o espaço público e tem nele seu principal suporte) quanto a musicalidade que acontece nas ruas (por diversos motivos, como ocupação histórica de um determinado espaço, festivais, espetáculos inicialmente criados para salas fechadas, etc.). Muitos dos artistas que se apresentam nas ruas e se consideramartistas deruatambémtrabalhamem eventos privados, salas de show, bareserestaurantes, porexemplo.Nacidadeestaspráticaseespaçosseentrelaçam, criando uma complexa rede cultural que congrega experiências variadas.

2 Ver, por exemplo: Sennett (2002); Jacobs (2011); Lefebvre (1991).

3 Neste trabalho adota-se a perspectiva do espaço público como um espectro, em constante disputa (Reia, 2017b), e ressalta-se que a expressão "espaço público" é usada de maneira ampla para descrever lugares da cidade que podem ser livremente acessados pelos cidadãos, gratuitamente (ruas, praças, avenidas, praias, etc.) ou através de um pagamento ou cadastro, no caso do transporte público. Contudo, vale ressaltar que, mesmo quando esses espaços podem ser publicamente acessados, não significa necessariamente que as pessoas terão acesso equitativo, já que classe, gênero, e raça influenciam a maneira pela qual se tem acesso à espaços públicos - e a privatização de espaços públicos toma muitas formas, visíveis (cercas, muros e grades) ou não (policiamento, iluminação e o próprio planejamento urbano). 
Ao ocupar as ruas, essas práticas acabam gerando tensões, uma vez que sua ocupação é não apenas espacial, mas também sonora, social e cultural. Para lidar com os conflitos de interesse criados pela música que ocupa as ruas, muitos munícipios tem optado por regular e controlar essas práticas, gerando debate público, leis, burocracia e, em alguns casos, truculência policial na observância das leis. O Rio de Janeiro aparece, aqui, como um importante objeto de estudo, por ser uma cidade historicamente ligada à uma cultura de "ocupação das ruas" (Herschmann, Fernandes, 2014), pelo lugar que ocupou recentemente na readequação das cidades aos megaeventos, pelos desdobramentos da política do choque de ordem e, ainda, por ser a primeira cidade do Brasil a regular a arte de rua. Ao mesmo tempo em que existe a regulação e as tentativas de controle da música nas ruas do Rio, há de se destacar também as persistências dos artistas através de diversas "táticas e astúcias" (De Certeau, 1995). Da desobediência civil ao hábito de andar com a lei dobrada no bolso ou salva no celular - e a própria participação dos artistas na criação da lei que os regula e nas políticas públicas de fomento os músicos da cidade acabam existindo e resistindo nas brechas possíveis.

Tendo essas discussões em mente e partindo de reflexões anteriores que conjugam abordagens interdisciplinares entre comunicação, cidades e música, este trabalho tem como objetivo central analisar como tem ocorrido a regulação e o fomento da música nas ruas do Rio em um contexto de megaeventos e transição política e econômica, ao mesmo tempo em que discute a experiência dos músicos e suas "táticas de tensionamento e até de resistência" (Herschmann, Fernandes, 2017; Reia, 2017a, 2017b, 2018). A análise construída aqui busca compreender as dinâmicas de ocupação e mobilização das ruas cariocas que gravitam em torno da música. Estas reflexões tomaram como referência entrevistas que foram realizadas com os atores e observação de campo levadas a cabo entre 2013 e 2017 nesta localidade.

\section{Rio de Janeiro: ruas que encantam, segregam e "(r)existem"}

Como ressaltam Rolnik e Fernandes (2016) o Rio hoje é uma metrópole que coloca em evidência muitas das questões e desafios que caracterizam as cidades do país na atualidade. Sua complexidade construída, simbólica e afetiva permeia as relações sociais, suas representações e as práticas aqui descritas: 
de processo decisório que passa ao largo e além das mediações e negociações no âmbito da esfera pública. O Rio, suas favelas, sua violência, seus projetos de intervenção urbanística e seus conflitos hegemonizam a ensaística sobre a cidade brasileira hoje, da mesma forma que São Paulo e suas periferias de trabalhadores protagonizaram as narrativas sobre as grandes cidades nos anos 1980 (Rolnik, Fernandes, 2016, p. 14).

Além dos impactos dos megaeventos e da crise que assola o estado, o Rio de Janeiro também passou por uma transição do governo municipal que tem reestruturado diversos órgãos e dado uma ênfase grande à ordem pública, fato que acaba moldando as ocupações e usos dos espaços públicos urbanos. O Rio acolheu megaeventos desde o início do século XX, tendência que se intensificou nos últimos anos e alterou a dinâmica do município, principalmente durante a gestão do prefeito Eduardo Paes (entre 2013 e 2016). Muitos pesquisadores têm se dedicado a estudar impactos e legados dos megaeventos nas cidades brasileiras e, especificamente, no Rio (Jennings e outros, 2014; Freitas e outros, 2016; Oliveira, 2015; Mascarenhas e outros, 2011; Cardoso, 2013; Herschmann, Fernandes, 2017).

Segundo Gaffney (2010), a tendência mundial da produção de megaeventos sugere que esses projetos deixam as comunidades envolvidas com grandes dívidas e reduções do espaço público. Os benefícios dos grandes eventos acabam indo para áreas e moradores de classes mais abastadas, assim como para os turistas internacionais que procuram entretenimento; dessa forma, "os aparelhos de segurança ampliados que se tornaram características básicas dos megaeventos globais e que efetivamente privatizam espaços públicos na cidade, instalando mecanismos de vigilância" (Gaffney, 2010, p. 18). Portanto, as consequências desses processos continuam mesmo depois que os eventos acabam e os turistas vão embora, deixando como parte do legado perdas significativas dos espaços públicos e o aumento do uso de tecnologias de vigilância e controle. No caso do Rio, além dos problemas assinalados, a crise econômica que se agravou após os jogos deixou a cidade em uma situação ainda mais complicada. A maioria dos atores mencionam uma nítida sensação de perda de dinamismo na vida cultural da metrópole. Nesse sentido, Sami Brasil (2017), uma das organizadoras do Baile Black Bom (evento de rua gratuito de grande popularidade no Centro do Rio) tece os seguintes comentários:

Apesar de ser muito importante, a ocupação cultural de rua no Rio frequentemente é uma coisa muito complicada, mal compreendida pelo poder público. Lamentavelmente é tudo muito sofrido e os 
artistas têm que passar por diversos processos e enfrentar muita burocracia. (...) Só que a gente sabe o que torna o Rio especial não são estes grandes museus, boulevares, aquários e outras obras faraónicas como estas que foram feitas aqui no Rio e que são geralmente executadas para enriquecer empresários e políticos corruptos. (...) O que torna o Rio uma cidade especial, diferenciada e que ajuda muito a economia local, dos pequenos comerciantes, são outras iniciativas: tradicionalmente quem traz dinamismo são as rodas, concertos e eventos de rua gratuitos, que mobilizam a população e que criam em geral um ambiente que facilitam os encontros entre diferentes tipos de pessoas (Brasil, 2017).

O Porto Maravilha é um importante exemplo das obras que tomaram a cidade antes dos Jogos Olímpicos de 2016 e das polêmicas que envolveram inúmeras remoções na região (Faulhaber, Azevedo, 2015). Na realidade, segundo Herschmann e Fernandes (2018) a zona portuária é uma área emblemática do projeto de construção de uma "cidade criativa"4 em curso. Para esses autores a recente reforma da zona portuária e o investimento em megaequipamentos culturais, especialmente em grandes museus ${ }^{5}$ e a aposta no potencial transformador e movente dos megaeventos - inclusive os grandes festivais de música e de artes - não vem ressignificando até o momento essa microrregião do Centro do Rio (Herschmann, Fernandes, 2014). Assim, assiste-se nesta urbe a aposta em um projeto de construção de uma cidade globalizada com um branding territorial fortalecido, a qual não leva em consideração as dinâmicas culturais presentes - os ecossistemas socioculturais existentes, de pouca

4 Muitos governos municipais em todo o mundo vêm adotando a conversão das metrópoles em cidades criativas como uma "alternativa redentora" as recorrentes crises globais. Modelo exportado pela Inglaterra no final dos anos de 1990 (por todo o mundo), poder-se-ia afirmar que é adotado hoje no Rio de Janeiro como uma espécie de ativismo municipal de tons mais ou menos neoliberais (dependendo da região). Assim, o que se constata no Rio é que há a adesão a um projeto coletivo para o território, o qual não são avaliados muito criticamente as implicações dos processos em curso e o quadro conceitual. Aliás, os conceitos de "indústrias criativas", "economia criativas" e "nação criativa" por exemplo, do qual derivou o conceito de "cidades criativas" (a maioria desses cunhados na primeira metade dos anos de 1990), incluem dinâmicas de produção, circulação e consumo de bens criativos e culturais abrangendo de forma difusa áreas como arquitetura, artes, artesanato, antiguidades, audiovisual, design, edição, videogames, softwares, moda, música, publicidade, televisão, teatro e rádio. De modo geral, os setores criativos constituem-se em um conjunto de setores absolutamente heterogêneos que adquirem, em geral, grande visibilidade graças a força e onipresença turismo globalizado e a força e da lógica do entretenimento no cotidiano (mais detalhes, conferir Reis, 2012). Segundo a UNESCO (Organização das Nações Unidas para a Educação, Ciência e Cultura), as "cidades criativas" reuniriam setores das indústrias criativas potentes no seu território (disponível em: http://en.unesco.org/creative-cities/home. Acesso em: 3 mar. 2017).

5 Em 2013 foi criado o Museu de Arte do Rio e, logo depois, em 2015, o Museu do Amanhã, ambos localizados nos arredores da Praça Mauá. 
visibilidade e/ou pouco institucionalizados - na metrópole. Diferentemente do que foi planejado pela tecnocracia do município, muitos atores vêm questionando - com o aprofundamento da crise econômica do Rio e do país - se esta área não viria se configurando em um espaço com muitas "conchas vazias"6, acessível apenas para um turismo elitizado.

A preocupação com a ordem pública tem ganhado espaço e visibilidade na agenda política do Rio, apesar de já existir há muitos anos. Mesmo que as manifestações musicais tomem as ruas da cidade há décadas, a busca da ordem pública tem avançado cada vez mais nas ações regulatórias dos representantes do poder público municipal. Na tentativa de ordenar esta cidade, muitas práticas tidas como irregulares pelo poder público e pela sociedade acabam sendo perseguidas e reprimidas. Neste contexto, a música tocada e vivenciada nas ruas acaba sofrendo com o peso da regulação de forma mais intensa, uma vez que os conflitos em torno do silêncio e da vida cultural acirram a disputa pelo direito à cidade.

O Rio é conhecido por sua efervescência cultural: especialmente por uma vibrante vida urbana e uma "cultura musical de rua" (Herschmann, Fernandes, 2014). O carnaval de rua do Rio é notório por tomar as ruas da cidade anualmente, mas vale destacar que várias outras manifestações artísticas têm usado os espaços públicos cariocas para promover seus trabalhos, criar novas experiências e impulsionar os encontros entre as pessoas. Essas iniciativas de grande capacidade movente foram denominadas por Herschmann e Fernandes (2014) como sendo capazes de construir significativas "territorialidades sônicomusicais"7 , as quais, pela ação do tempo, promovem expressivas modificações no imaginário e cotidiano urbano. Ou seja, essas "territorialidades" - pela recorrência da sua presença, intensidade dos afetos, enorme mobilização,

6 Muitas vezes o poder público investe na instrumentalização da cultura como estratégia de desenvolvimento territorial e na construção de onerosos equipamentos culturais que nem sempre trazem os resultados esperados. Como sugere Vivant, trazer de "paraquedas" um equipamento cultural sem a articulação não só um projeto específico, mas também uma articulação com os atores e as tradições culturais do território pode se constituir em um procedimento vão e arriscado que pode levar ao desperdício de recursos importantes na construção dos chamados "elefantes brancos" ou "conchas vazias" (Vivant, 2012).

7 Com a noção "territorialidades sônico-musicais" busca-se valorizar a importância da música e das inúmeras sonoridades presentes no cotidiano das cidades para os processos de "(re)territorialização" (Haesbert, 2010) que serão realizados pelos atores pesquisados. Muitas vezes a decisão da área que será ocupada com música leva em conta não só a circulação dos atores, mas também o fluxo e a intensidade dos fluxos sônicos do local (Herschmann, Fernandes, 2014). Essas territorialidades - mais ou menos temporárias -, pela sua regularidade, geram uma série de benefícios locais diretos e indiretos para o território (permitindo até o incremento das atividades socioeconômicas locais). Aliás, como sugerem alguns autores de Sound Studies (Labelle, 2010; Kittler, 1999), essas territorialidades são relevantes porque afetam o ritmo, o imaginário e os corpos no dia a dia, reconfigurando de alguma maneira os territórios: gerando novas cartografias sônicas ou acústicas da cidade. 
pluralidade e pela sua multiplicação em diversas áreas - acabam produzindo efeitos expressivos em partes da cidade ou na urbe como um todo.

Em um cenário de disputa da espacialidade urbana, a música nas e das ruas vem ganhando visibilidade em algumas cidades brasileiras - muitas vezes de forma negativa, como algo a ser controlado, cerceado ou mesmo extinto. Consequentemente, muitos municípios começaram a pensar formas de controlar e organizar apresentações que acontecem nos espaços públicos, e assim surgem diversas leis e regulamentações que tentam de alguma forma tornar as performances mais previsíveis, assegurando que elas não distorçam a mobilidade e a ordem esperada no espaço urbano. O Rio passou, ao longo dos últimos anos, por variados processos que transformaram o território - o desenho urbano da cidade, aliados à uma maior abertura à comunidade internacional através dos megaeventos - buscando atrair mais turistas e investimentos para esta suposta "emergente cidade criativa". Com o destaque midiático e a nova posição do município enquanto lugar para se estar, muitos artistas de rua escolheram o Rio como local de trabalho nos últimos anos. ${ }^{8}$ Vários grupos musicais que atuam na rua começaram a ganhar visibilidade na década passada através não só das apresentações realizadas em espaços públicos, ${ }^{9}$ mas também dos conteúdos divulgados nas redes sociais e da cobertura da mídia tradicional.

No início de agosto de 2016, durante os Jogos Olímpicos, por exemplo, a mídia noticiou que artistas de rua chegavam a faturar até $\mathrm{R} \$ 2$ mil por dia no Boulevard Olímpico, ${ }^{10}$ atraindo pessoas que trabalhavam ou não com arte nas ruas previamente, mas que viram ali uma oportunidade de renda, visibilidade e de participar daquele encontro, como músicos, estátuas vivas ou homemorquestra. ${ }^{11}$ No mesmo período, Amir Haddad e seu Grupo Tána Rua conseguiram articular uma curadoria de artistas de rua que se apresentaram no Boulevard Olímpico, coordenado pela Riotur e com cachês. O Boulevard Olímpico, com sua nova cara, calçadão, museu e murais de grafite enormes, fez muito sucesso durante as olimpíadas, atraindo milhões de visitantes e, consequentemente, muitos artistas que não faziam parte da curadoria do Tá na Rua.

De fato, a atenção que tem sido dada aos artistas de rua vem aumentando nos últimos anos. No dia 6 de junho de 2015 o jornal O Globo publicou uma matéria intitulada "Bandas ocupam praças, calçadas e trens do Rio, passam o chapéu e multiplicam vendas de discos"12, em que fala de diversas bandas que

8 Ver Bottari (2012).

9 Exemplos deste tipo de ocupação musical podem ser conferidos no seguinte link: http://www. cartografiamusicalderuadocentrodorio.com.

10 Ver Rodrigues (2016).

11 Ver Lins (2016).

12 Ver Essinger (2015). 
tocavam nos espaços públicos do Rio de Janeiro, como Tree, Astro Venga, Ma Non Troppo, Bagunço, Beach Combers, Dominga Petrona e Os Camelos. Há, segundo a matéria, um crescente interesse nesse tipo de apresentação; os músicos entrevistados ressaltam a dificuldade em se tocar em casas fechadas e de se ter "espaço" para os artistas hoje em dia. Mostra também a prática da venda de CDs e de como a rua pode trazer um bom retorno financeiro e visibilidade. $O$ fato de haver cada vez mais grupos nas ruas da cidade, já na época da entrevista, não incomodava alguns dos entrevistados.

Outro fator que impulsionou o aumento da ocupação das ruas por artistas nos últimos anos foi a aprovação da lei que regulamentou a arte de rua em 2012 (Lei 5.429/2012), conhecida também como a "Lei do Artista de Rua" aprovada em grande medida pela capacidade de negociação política do diretor teatral Amir Haddad: “(...) foi difícil aprovar esta lei, contamos com o apoio de inúmeros grupos e movimentos culturais importantes (...) há uma vida cultural que acontece nos espaços públicos da cidade que ganhou mais respaldo com a lei" (Essinger, 2015).

Apesar de continuarem trabalhando informalmente e dependendo das doações para financiarem sua arte, os artistas contam com a ideia de proteção contra os abusos da polícia. Por mais que se apresentar em espaços públicos não fosse uma atividade ilegal, também não significava que fosse legal. As fronteiras dos ilegalismos (Foucault, 1999; Telles, 2011) da ocupação do espaço público para ganhar a vida com arte de rua não eram muito evidentes até o fim da primeira década do século XXI. Como salienta o músico Miguel Maron, do grupo de fanfarra Os Siderais: "(...) esses músicos que decidem tocar aqui e acolá estão bem mais suscetíveis a terem que enfrentar a polícia, moradores locais e o poder público na ocupação das ruas" (Maron, 2014).

Justamente por ocupar esses espaços liminares (Bywater, 2007) que escapavam aos binários formal e informal, legal e ilegal, profissional e amador, vagabundo e artista, essas pessoas acabavam sujeitas às arbitrariedades daqueles responsáveis pela observância da lei e manutenção da ordem pública - sendo esta entendida de maneira muito restrita pela gestão do prefeito Paes e, atualmente, pela gestão de Crivella (período de 2016-2019) ${ }^{13}$ - afetando diretamente o modo como as pessoas usam as ruas para sobrevivência.

13 Ver, por exemplo, o projeto de lei 87/2017, proposto pelo Poder Executivo municipal, atual Lei Ordinária 6.235/207 que institui o Fundo Especial de Ordem Pública (Feop). 


\section{Regulações e astúcias}

Ao falar da cidade do Rio de Janeiro, das normas e políticas que impactam na organização e usufruto dos espaços públicos, faz-se necessário mencionar os esforços tanto de regulação de atividades vistas como "desordeiras", quanto a instauração e observância da ordem pública. Em 2009 foi criada a Secretaria Especial de Ordem Pública (Seop), pelo então prefeito Paes, com o intuito de atuar em conjunto com outros órgãos municipais de transporte e limpeza e com a Guarda Municipal para manter a ordem da cidade através da "Operação Choque de Ordem". O choque de ordem, como ficou conhecido, reacendeu debates sobre o direito à cidade e a ocupação de espaços públicos cariocas, principalmente pelos indivíduos que fazem usos das ruas para ganhar a vida.

No caso dos artistas que se apresentam nas ruas, diante da repressão policial, da falta de apoio da prefeitura e da escassez de políticas de fomento, eles identificaram uma alternativa na proteção e legalização de suas atividades através de uma norma jurídica municipal, discutida juntamente com articulações em torno de uma política cultural que proporcionasse sustentabilidade financeira e legitimação das atividades desenvolvidas por diversos grupos de artistas no Rio. Segundo o músico Cristian Kiffer, do grupo Dominga Petrona, a situação dos artistas tinha melhorado um pouco nas ruas com a nova lei, mas infelizmente a repressão e exigências têm aumentado significativamente na gestão Crivella "(...) os policiais nem sempre respeitam a lei e ficam cobrando mais papelada e autorizações" (Kiffer, 2017).

Importante ressaltar que os artistas que se apresentam nas ruas enfrentam os impactos de normas jurídicas que não dizem respeito apenas às performances no espaço público, mas também outros temas acabam enquadrando-os, como normas sobre silêncio (lei municipal 3.268/01 e lei estadual 126/77), comércio ambulante (lei municipal 1.876/92 e decreto municipal 31.519/09), monitoramento e segurança pública, ordem pública (lei municipal 6.235/17), apresentações dos espaços públicos (lei municipal 5.429/12) ou no metrô (projeto de lei estadual 2.958/14), entre outras. Essa trajetória e debate jurídico é relevante porque o Rio de Janeiro foi a primeira cidade brasileira a criar uma lei municipal que regula a atividade dos artistas de rua, com três artigos que, entre outras coisas, regulam as manifestações culturais sem autorização prévia, desde que sigam alguns requisitos, como horários, potência de equipamentos sonoros, disposição espacial da apresentação, etc. Pouco tempo depois, várias cidades brasileiras também começaram a discutir a questão da ocupação dos espaços públicos por performances artísticas.

O caso do Rio de Janeiro é emblemático não apenas por ter sido a primeira cidade, mas também pelo engajamento dos artistas no processo de regulação 
da arte de rua no município. No caso do Rio, a lei veio do esforço coletivo de muitos atores que se envolveram de fato na formulação e implementação da lei para garantir os direitos dos artistas de rua na cidade. A "Lei do Artista de Rua" não surgiu de cima para baixo, como imposição do poder público: foi negociada com os artistas, assim como foram negociadas políticas de financiamento da arte de rua que promovessem a continuidade das atividades nos espaços públicos cariocas. Tudo isso dentro de um movimento que surge no Fórum de Arte Pública encabeçado por Amir Haddad, com participação intensa de grupos como o Tá na Rua, Off-Sina, Grande Companhia Brasileira de Mysterios e Novidades entre outros.

O conceito de Arte Pública como uma política em construção, um serviço público oferecido à cidade e seus cidadãos, retira a marginalidade da rua de seu nome e incorpora uma visão da arte que acontece nas ruas como aquela sendo doada como parte da vida cultural urbana - movimento que contribui para a legitimação e reconhecimento da arte de rua. Algumas das frases mais emblemáticas do movimento de arte pública carioca ${ }^{14}$ sublinham a força que a ideia do público adquire enquanto um bem para a cidade e para a população, ao mesmo tempo em que se colocam como "forças desarmadas da população" para construir uma cidade "para quem vive nela". Também enfatizam a proposta de que não se pode vender o que se tem de melhor para dar: nesse caso trata-se da arte apresentada nos espaços públicos.

As propostas, conceitos e "lemas" do movimento da arte pública carioca deram respaldo para a criação da Lei do Artista de Rua e de seus desdobramentos junto à prefeitura e à Secretaria Municipal de Cultura (SMC), como a criação do Festival Carioca de Arte Pública. ${ }^{15}$ A constante oposição entre "protesto" e "proposta" está enraizada nas atividades do Fórum de Arte Pública, colocando a arte pública como uma alternativa para a cidade ao afirmar que eles não são um protesto, são "uma proposta para a cidade", nas palavras do diretor de teatro do grupo Tá na Rua Amir Haddad (2014). Essa mudança de perspectiva sobre a arte de rua representa também uma atuação política que ressalta parceiros e opositores, enquanto ajuda a fragmentar o cenário da arte de rua carioca, que já é bastante complexo, fluído e multifacetado.

14 Nas observações de campo realizadas encontrou-se com alguma recorrência as seguintes frases usadas em panfletos e cartazes: "A cidade é para quem vive nela, não para quem vive dela"; "Somos as forças desarmadas da população"; "Não somos um protesto, somos uma proposta"; "Não podemos vender o que temos de melhor para dar"; "Artistas públicos, cidade pública, arte pública".

15 Entre 2014 e 2016 foram realizadas três edições do Festival Carioca de Arte Pública, com diferentes proporções, orçamento e tipos de ocupações dos espaços públicos do Rio. No término da edição de 2016, ainda era incerta a realização de uma quarta edição em 2017, com a troca de governo e crise que mudaram a abertura institucional e as janelas de oportunidades para os artistas. 
Apesar de todos os pontos positivos da aprovação da"Lei do Artista de Rua" em termos de regulação e proteção de diversas performances que acontecem na urbe, esta também aponta problemas importantes ao se discutir o "direito à cidade". Mesmo que a regulação possa proteger os artistas em uma cidade como o Rio, ao mesmo tempo ela exclui outras práticas, estando todas sujeitas à arbitrariedade da observância da lei por todo o sistema que se encontra entre a lei e a rua - uma vez que a norma jurídica, em si, não garante a legalidade e normalidade da atividade dos artistas aos olhos de todos os agentes públicos (da burocracia administrativa às forças de segurança) ${ }^{16}$, levando os artistas a andarem com a "lei no bolso" para fazê-la "valer mais". Segundo Wagner José, um dos músicos entrevistados: "todo mundo tem que andar com a lei gravada no celular, tem que tê-la para qualquer eventualidade, sempre na bolsa do instrumento" (José, 2016). Além disso, ao ter uma lei que os protegem, os artistas também se distanciam de outros trabalhadores que trabalham na marginalidade dos espaços, lidando com ilegalismos (tais como os vendedores ambulantes). Ao mesmo tempo, o Fórum de Arte Pública e o Festival Carioca de Arte Pública ainda não contemplam grande parte dos artistas da cidade - há os que ficam de fora dessas iniciativas, e os quais seguem se apresentando de forma atomizada e dispersa pela cidade, por não terem acesso ao debate ou por não se identificarem com o movimento de arte pública, por exemplo.

Parte-se do pressuposto de que o envolvimento dos artistas (e suas redes sociais mobilizadas) e a participação ativa na proposição de políticas públicas que contemplem seus interesses é muito relevante (Reia, 2017a). A inserção de parte dos artísticas na disputa política na cidade está atrelada à sua institucionalização - que pode ser comprovada pela ligação com a SMC e a demanda de se criar um "departamento" dentro do órgão que fosse dedicada à arte pública, segundo Haddad (2014). Além do poder público, os cidadãos teriam um papel importante para fomentar e ajudar a sustentar a arte pública e os artistas na cidade.

Enxergando além da articulação política, porém, vislumbram-se os artistas não apenas atuando como cidadãos e defendendo os interesses de seu movimento através da participação democrática, como também é possível entender as potencialidades de uma arte pública, nas ruas, capaz de promover encontros nos espaços públicos. A própria participação e interação dos cidadãos nas performances artísticas que acontecem nas ruas é pré-requisito para a arte de rua aconteça - e muitos espetáculos trazem à tona discussões políticas e socioculturais bastante atuais que são levadas pelo público depois que as

16 Ver Nitahara (2016). 
performances terminam. É impossível ter um denominador comum em termos de conteúdo das performances, dada a variedade de práticas e artistas que se apresentam nos espaços públicos, mas, como aponta Haedicke (2013), mesmo que as performances não sejam em si políticas, só o fato de ocuparem espaços públicos que não foram originalmente desenhados para este fim, já as tornam um ato político.

A marginalização enfrentada por muitos artistas ao longo dos anos também vale ser mencionada, já que por mais que a arte de rua venha recebendo crescente atenção da mídia, do governo e da academia, ainda é considerada uma atividade marginal e/ou sem grande relevância cultural. Embora essas visões não sejam completamente verdade e não cubram a multiplicidade de práticas artísticas que acontecem nas ruas, a informalidade enfrentada por muitos dos artistas tende a empurrá-los para uma condição marginal, ao mesmo tempo em que a rua não é uma garantia de palco e nem de reconhecimento sociocultural.

Além disso, existem também ameaças recorrentes à legalidade da música que é apresentada nas ruas, como projetos de lei que atacam espaços públicos, vida noturna e barulho, por exemplo. Em maio de 2015 a vereadora Leila do Flamengo - responsável, por exemplo, pelo projeto de lei que pretendia cercar a praça São Salvador, conhecida por sua efervescente vida noturna, muito ligada à música - propôs o Projeto de Lei 1.267/15, que visava alterar o artigo $1^{\circ}$ da Lei do Artista de Rua para que os artistas se apresentassem apenas em espaços públicos que não tivessem "moradias em seu entorno". A vereadora coloca a arte de rua em uma posição de "bagunça generalizada em alguns logradouros públicos", de acordo com o texto do projeto, usando mais uma vez a praça São Salvador como centro da discussão, e tentando inviabilizar uma atividade garantida por lei em todo o município. Se essa lei vier a ser aprovada, avalia-se que ficaria muito difícil, para os artistas, seguirem realizando suas apresentações em espaços públicos que não tivessem moradias próximas. O vereador Reimont Luiz Otoni Santa Bárbara (principal interlocutor dos artistas no processo de criação e aprovação da Lei do Artista de Rua) convocou os artistas quando percebeu que este projeto de lei entraria na ordem do dia e essas redes e suas lideranças se organizaram rapidamente, de um dia para o outro, para ocupar a câmara municipal e pressionar para que não fosse aprovado (Santa Bárbara, 2017). Para Richard Riguetti, do grupo Off-Sina, essa perseguição aos artistas de rua não tem fundamento, já que os bares - referindo-se principalmente à Praça São Salvador, um dos principais objetivos da vereadora - “(...) funcionam muito além do horário máximo permitido às apresentações dos artistas de rua" (Riguetti, 2015). 
Segundo Reimont, a estratégia para barrar esse tipo de retrocesso é promover a participação dos agentes interessados, indicando a importância dos direitos assegurados pela "Lei do Artista de Rua" - e de se andar com a lei, mostrando a todos que a mesma existe e que deve ser respeitada (Santa Bárbara, 2017). Com a gestão do prefeito Crivella a ênfase na ordem pública se intensificou (de modo geral, essa gestão tem dificultado ou interditado a vida noturna da cidade e outras atividades que se desenrolam nos espaços públicos), ficando explicitado ainda mais pela aprovação da Lei Ordinária 6.235/2017 (que institui o Feop). A situação da legalidade dos artistas de rua em sua ocupação dos espaços públicos cariocas é incerta, nos próximos anos, evidenciando a dificuldade de se manter a continuidade de algumas normas, políticas públicas e relações construídas especificamente com gestões que muitas vezes se desmancham com a troca de prefeito. Essas transições acabam afetando muito do que foi construído anteriormente e pode ser que os artistas se vejam em uma situação tão ruim (ou pior) do que o período anterior à lei. Isso evidencia que por mais que a regulação da arte de rua seja proteção, ela é, assim como os palcos no qual acontece, efêmera e suscetível às mudanças constantes. Aparentemente, a política em construção para a arte pública carioca continuará sendo construída e disputada nos próximos anos. Entretanto, muitos dos artistas mais experientes (que são ativistas do espaço público há várias décadas) acreditam que mesmo com a aprovação de leis mais repressivas a "cultura de rua" terá uma continuidade, ainda que submersa no território:

(...) independente do que venha a acontecer nos próximos anos, pode-se afirmar sem medo que nós artistas, que estamos nos espaços públicos, especialmente aqueles que estamos há muito tempo na estrada, já vimos muita coisa e sabemos até como sobreviver de forma submersa e invisível na cidade [...] afinal, em grande medida, nosso trabalho se desenvolveu desta maneira e alcançava resultados significativos, construindo uma forte tradição cultural desta cidade (...). (Riguetti, 2015)

\section{Música no MetrôRio}

As incertezas e condições de atuação são ainda piores no caso dos músicos do metrô no Rio de Janeiro. A ocupação de espaços do metrô por artistas de rua, vendedores ambulantes, pedintes e evangelizadores ocorre há vários anos. Recentemente, a discussão sobre a ocupação irregular de espaços do metrô foi reacendida com foco nos artistas (principalmente músicos), que vinham se apresentando nos vagões e sendo retirados a força pelos seguranças. Vídeos compartilhados em redes sociais mostravam seguranças retirando dois 
músicos do trem pelo pescoço, de forma violenta, apesar das reclamações de diversos passageiros. O incidente acabou sendo veiculado pela mídia tradicional, gerando debate sobre a atuação de músicos dentro dos vagões. ${ }^{17}$

O MetrôRio proíbe que artistas se apresentem em vagões, sendo que esse tipo de atividade, sempre que identificada, é reprimida pelos funcionários do metrô. O aumento do número de artistas e da atenção que a questão começava a receber já preocupava os artistas em 2013. ${ }^{18}$ Em setembro de 2014 o MetrôRio divulgou uma solução para estes impasses, porém não chegou perto dos desejos dos artistas: na verdade, a proposta do metrô, um edital para o projeto “Estação da Música", causou raiva e indignação, com diversas pessoas comparando a regulação da atividade no metrô com trabalho escravo. Ao mesmo tempo em que não receberiam nenhum apoio financeiro ou de infraestrutura, os artistas não poderiam passar o chapéu, mostrando que o equilíbrio de interesses estava longe do ideal e que a valorização ou mesmo a legitimação do trabalho desses artistas não aconteceu. Os músicos teriam de passar por uma espécie de audição, serem selecionados de acordo com seus talentos, mas não teriam nenhuma contrapartida além da "visibilidade" de seus trabalhos. Para piorar ainda mais a proposta, os artistas deveriam ceder seus direitos de imagem, voz e nome para a divulgação do projeto, enquanto nem mesmo a garantia de continuidade de suas apresentações eram garantidas.

Vê-se que as camadas de normas vão criando obstáculos para lidar com questões pontuais cotidianas que fogem ao binarismo do legal e ilegal. A falta de conhecimento e diálogo com artistas que conhecem a realidade das ruas e vagões pela cidade leva à uma regulação míope, que vem de cima pra baixo e esmaga nuances e demandas de quem precisa dela para continuar trabalhando sem sofrer violência dos agentes de segurança. $O$ debate público e a mobilização dos artistas em torno da questão levaram o MetrôRio a suspender o edital poucos dias depois do seu lançamento, para reformulá-lo e torná-lo atrativo aos músicos.

Nos últimos anos a música nos vagões do metrô não deixou de existir, sendo que os músicos usam de astúcias entrelaçadas com atividades cotidianas para passarem incólumes. Em maio de 2015, a imprensa ainda cobria a presença de músicos no vagão, apesar da proibição. Na época já existia um projeto de lei sobre o tema (PL 2.958/2014) que tramitava na Assembleia Legislativa do Estado do Rio de Janeiro (Alerj), sem nenhuma movimentação desde agosto de 2015. Esse projeto de lei (PL), de autoria do deputado André Ceciliano, estipula em

17 Ver repercussão na matéria Músicos são agredidos por seguranças do metrô, no jornal O Dia, publicada em 21 dez. 2015.

18 Ver Bessa (2013). 
sete artigos a regulação das apresentações culturais no interior dos vagões do Rio de Janeiro. O PL regulamenta apresentações musicais e de poesia, a partir de um cadastro prévio de artistas e sem a garantia de gratuidade no transporte. Também limita os horários de apresentação - fora dos horários de maior circulação de passageiros - e impede a cobrança de cachê, permitindo apenas a doação espontânea (passar o chapéu), desde que a apresentação não incomode os passageiros, que podem pedir a interrupção da mesma. Esse projeto sanaria um dos maiores impasses entre músicos e metrô, que é a demanda/proibição de apresentações dentro dos vagões dos trens.

Em outubro de 2015 o projeto de lei foi debatido na Alerj, sendo que "durante o debate, surgiram propostas como a criação de vagões exclusivos para músicos nos trens e no metrô do Rio. Questões como a cobrança de direitos autorais pelas canções tocadas pelos músicos foram discutidas", de acordo com matéria Projeto de lei que autoriza músicos em trens e metrô é discutido na Alerj, publicada no portal $G 1$. Os músicos também pediram algumas modificações no projeto proposto, como a centralização do cadastro e a gratuidade do transporte. As concessionárias de transporte argumentam que a proibição de apresentações culturais nos vagões segue modelos adotados em outras cidades pelo mundo e se baseiam, principalmente, em questões de segurança dos usuários.

Após a proposição do projeto de lei 2.958/2014 os músicos perceberam que era preciso se organizar para se opor às agressões recorrentes, garantir seus interesses, demandar legalidade e buscar a legitimação de suas atividades - e é a partir disso que surge o Coletivo AME (de artistas metroviários). Os artistas ressaltam a necessidade do "fim do autoritarismo das concessionárias" que agem de forma violenta contra os artistas, assim como demandam o fim da impunidade das concessionárias e a garantia do "direito à livre manifestação cultural nos transportes públicos por meio da arte itinerante dentro dos vagões". A justificativa para a legalização dos artistas nos vagões do metrô se baseia na importância da arte para a transformação do cotidiano dos envolvidos e para a promoção de encontros e experiências.

No início de 2016 o MetrôRio lançou um novo projeto, dessa vez chamado Palco Carioca, no qual disponibiliza palcos em três estações: Carioca, Siqueira Campos e Maria da Graça. No site do metrô, o Palco Carioca é apresentado como um projeto que tem como objetivo "incentivar talentos, realizar o intercâmbio cultural e dar oportunidade para os músicos apresentarem seu trabalho ao público que transita pelas estações do metrô". O site fornece um espaço para que os músicos agendem suas apresentações, fotos dos palcos. A agenda dos shows nas estações participantes, o regulamento para que o artista participe 
do projeto e uma seção com perguntas frequentes. Algumas das regras são bastante estritas e não combinam muito com o trabalho de artistas de rua, como por exemplo, evitar a interação e participação do público nas apresentações e a comercialização de CDs. Nas palavras de Wagner José, que tentou se apresentar no projeto uma vez: "não gostei muito porque ali as pessoas passam sempre com pressa, querem pegar o seu trem ou então chegar do trabalho em casa e não tem nada a ver com a proposta da rua, mas o que não gostei mesmo são das condições que eles impuseram aos artistas, você não pode comercializar nada" (José, 2016).

Mesmo com a implantação do projeto Palco Carioca, os artistas continuaram se apresentando nos vagões e demandando o direito de estar ali, comparando a atividade de se apresentar ilegalmente e driblar os seguranças com uma "caçada de gato e rato", de acordo com matéria no portal R7 Artistas do Rio 'driblam' vigias do metrô. De tempos em tempos, denúncias de agressão de artistas vinham à tona e colocavam lenha na fogueira do debate público em torno do tema. Até a aprovação do projeto de lei que tramita na Alerj, ou o diálogo e formulação de políticas de apoio aos artistas metroviários, eles viverão nas margens legais de atuação, tendo como tática a desobediência civil através da atuação irregular nos vagões ou a participação legal e reconhecida no projeto Palco Carioca.

\section{Considerações finais}

Ao se olhar para a música que acontece nos espaços públicos urbanos e os mecanismos existentes para controlá-la, muitas questões sobre as dinâmicas de poder e desigualdade nas cidades contemporâneas vêm à tona. Justamente por ocupar um lugar de disputa espacial e simbólica, os músicos e sua luta pelo direito à cidade, contra políticas culturais problemáticas e diante das dificuldades de acesso aos espaços públicos merecem uma análise atenta, principalmente se considerarmos a música nas ruas como um processo comunicacional. As tentativas de regular e controlar essas práticas podem nos dizer muito sobre as lógicas de determinados momentos históricos, evidenciando a complexidade do cotidiano em ambientes urbanos densos e complexos.

Apesar do Rio de Janeiro ter sido uma cidade pioneira na regulação da arte de rua, vem enfrentando uma grave crise econômica, uma arbitrária política de ordenamento urbano que nem sempre leva em conta o interesse público e, ainda, a instabilidade de políticas que fomentem a música feita nas ruas de forma duradoura e independente do gestor que assume a prefeitura. Mesmo as apresentações musicais históricas, ligadas à territórios específicos enfrentam problemas de continuidade em função da falta de apoio da atual 
gestão municipal. Esse cenário faz com que, tanto nas ruas quanto no metrô, a regulação das performances que acontecem nas ruas evidencie, por um lado, que a "Lei do Artista de Rua" ainda não é completamente respeitada pelos agentes de segurança pública, pois os artistas frequentemente devem apresentá-la para não serem cerceados ou punidos; e por outro lado, os músicos do metrô aguardam uma lei que tarda a ser discutida e sancionada, mantendo uma situação de marginalidade e irregularidade nas apresentações dos vagões, empurrando os artistas para a desobediência civil.

De todo modo, não somente as disputas continuam e tendem a se intensificar - na medida em que a busca pela ordem pública enxerga os músicos como parte da desordem a ser contida - como a pluralidade de práticas de ressignificação e "(r)existência" dos artistas nos espaços da cidade seguem sendo realizadas com criatividade e astúcia, ainda que na condição de iniciativas pouco visíveis e situadas nas fronteiras dos ilegalismos.

\section{Referências}

AIELLO, Giorgia; TOSONI, Simone. Going about the City. International Journal of Communication, v. 10, p. 1252-1262, 2016.

ATTALI, Jacques. Noise: The Political Economy of Music. Minneapolis: University of Minnesota Press, 2009.

ARTISTAS do Rio 'driblam' vigias do metrô. R7, São Paulo, 5 mar. 2016. Disponível em: https://noticias.r7.com/rio-de-janeiro/artistas-do-rio-driblam-vigias-nometro-05032016. Acesso em: 16 nov. 2017.

BESSA, Priscila. Músicos driblam proibição e quebram a monotonia dos vagões de metrô no Rio. IG, Rio de Janeiro, 16 jan. 2013. Disponível em: http://ultimosegundo. ig.com.br/brasil/rj/2013-01-16/musicos-driblam-proibicao-e-quebram-amonotonia-dos-vagoes-de-metro-no-rio.html. Acesso em: 16 nov. 2017.

BOTTARI, Elenilce. Artistas de rua vindos até de outros países se multiplicam pelo Rio. 0 Globo, Rio de Janeiro, 1 set. 2012. Disponível em: https://oglobo.globo.com/rio/ artistas-de-rua-vindos-ate-de-outros-paises-se-multiplicam-pelo-rio-5976856. Acesso em: 15 nov. 2017.

BRASIL, Sami. Entrevista realizada por Micael Herschmann e Cíntia Sanmartin Fernandes, em 17 de maio de 2017.

BURD, Gene; DRUCKER, Susan J.; GUMPERT, Gary. Urban Communication Reader. Cresskill: Hampton Press, 2007.

BYWATER, Michael. Performing Spaces: Street Music and Public Territory. Twentieth- 
Century Music, v. 3, n. 1, p. 97-120, 2007.

CARDOSO, Bruno de Vasconcelos. Megaeventos esportivos e modernização tecnológica. Horizontes Antropológicos, ano 19, n. 40, p. 119-148, 2013. http://dx.doi.org/10.1590/S0104-71832013000200005.

CARTOGRAFIA MUSICAL DE RUA DO CENTRO DO RIO. Disponível em: http://www. cartografiamusicalderuadocentrodorio.com. Acesso em: 6 out. 2017.

CASTELLS, Manuel. The Informational City. Oxford: Blackwell Publishers, 1989.

DE CERTEAU, Michel. A invenção do cotidiano. Petrópolis: Ed. Vozes, 1995.

DICKINSON, Greg; AIELLO, Giorgia. Being Through There Matters: Materiality, Bodies, and Movement in Urban Communication Research. International Journal of Communication, v. 10, p. 1294-1308, 2016.

ESSINGER, Silvio. Bandas ocupam praças, calçadas e trens do Rio, passam o chapéu e multiplicam vendas de discos. O Globo, Rio de Janeiro, 06 jun. 2015. Disponível em: https://oglobo.globo.com/cultura/musica/bandas-ocupampracas-calcadas-trens-do-rio-passam-chapeu-multiplicam-vendas-dediscos-16362472. Acesso em: 15 nov. 2017

FAULHABER, Lucas; AZEVEDO, Lena. Remoções no Rio de Janeiro. Rio de Janeiro: Mórula Editorial, 2015.

FREITAS, Ricardo F.; LINS, Flávio; SANTOS, Maria Helena C. (orgs.). Megaeventos, comunicação e cidade. Curitiba: Editora CRV, 2016.

FOUCAULT, Michel. Vigiar e Punir. Petrópolis, Vozes, 1999.

GAFFNEY, Christopher. Mega-events and socio-spatial dynamics in Rio de Janeiro, 1919- 2016. Journal of Latin American Geography, v. 9, n.1, p. 7-29, 2010. https://doi.org/10.1353/lag.0.0068.

GEORGIOU, Myria. Media and the City. Cambridge: Polity Press, 2013.

HADDAD, Amir. Entrevista realizada por Micael Herschmann e Cíntia Sanmartin em 25 de junho de 2014.

HAEDICKE, Susan C. Contemporary Street Arts in Europe: Aesthetics and Politics. Hampshire: Palgrave Macmillan, 2013.

HAESBAERT, Rogério. 0 mito da desterritorialização. Rio de Janeiro: Bertrand Brasil, 2010.

HERSCHMANN, Micael; FERNANDES, Cíntia S. Música nas ruas do Rio de Janeiro. Rio de Janeiro: Ed. Intercom, 2014. 
. Repensando a relevância dos microeventos para a cidade do Rio de Janeiro. In: COUTINHO, Iluska; PEREIRA, Ariane (orgs.). Comunicação e Cidade Espetáculo. São Paulo: Ed. Intercom, 2017.

. Entre as conchas vazias e a potencialidade das dinâmicas criativas urbanas cotidianas na área do porto do RJ. In: FERNANDES, Cíntia S.; HERSCHMANN, Micael (orgs.) Cidades Musicais: Comunicação, Territorialidade e Política. Porto Alegre: Ed. Sulina, 2018.

JACOBS, Jane. The Death and Life of Great American Cities. New York: Modern Library, 2011.

JASSEM, Harvey; DRUCKER, Susan J; BURD, Gene. Urban Communication Reader. Cresskill: Hampton Press, 2010.

JENNINGS, Andrew e outros. Brasil em Jogo. São Paulo: Boitempo, 2014.

JOSÉ, Wagner. Entrevista realizada por Micael Herschmann e Cíntia Sanmartin Fernandes em 28 de junho de 2016.

KITCHIN, Rob. Making Sense of Smart Cities: Addressing Present Shortcomings. Cambridge Journal of Regions, Economy and Society, Cambridge, vol. 8, n. 1, p. 131-136, mar 2015. https://doi.org/10.1093/cjres/rsu027.

LABELLE, Brandon. Acoustic Territories. Nova York: Continuum, 2010.

KIFFER, Cristian. Entrevista realizada por Micael Herschmann e Cíntia Sanmartin Fernandes, em 2 de agosto de 2017.

KITTLER, Friederich. Gramophone, Film, Typewrither. Stanford: Stanford University Press, 1999.

; GRIFFIN, Matthew. The City as a Medium. New Literary History, v. 27, n. 4, p. 717-729, 1996.

LEFEBVRE, Henri. Le droit à la ville. Paris: Éditions Anthropos, 1968.

The Production of Space. Oxford: Blackwell Publishers, 1991.

LEMOS, André; MONT`ALVERNE, Adelino. Cidades Inteligentes no Brasil. Revista de Comunicação Midiática, v. 10, n. 3, p. 21-39, 2015.

LINS, Marina Navarro. A cada dia, novos artistas de rua lotam o Boulevard Olímpico. Extra, Rio de Janeiro, 9 ago. 2016. Disponível em: https://extra.globo.com/noticias/ rio/a-cada-dia-novos-artistas-de-rua-lotam-boulevard-olimpico-19889343. html. Acesso em: 15 nov. 2017.

LOUKAITOU-SIDERIS, Anastasia; EHRENFEUCHT, Renia. Sidewalks. Cambridge: MIT Press, 2009. 
MARON, Miguel. Entrevista realizada por Micael Herschmann e Cíntia Sanmartin Fernandes em 11 de julho de 2014.

MASCARENHAS, Gilmar; BIENENSTEIN, Glauco; SÁNCHEZ, Fernanda (Orgs.). 0 jogo continua. Rio de Janeiro: EDUERJ, 2011.

MATTERN, Shannon. Deep Mapping the Media City. Minneapolis: University of Minnesota Press, 2015.

. Code and Clay, Data and Dirt. Minneapolis, University of Minnesota Press, 2017.

MCQUIRE, Scott. The Politics of Public Space in the Media City. First Monday, Special Issue \#4, fev. 2006.

. The Media City. Londres: Sage Publications, 2008.

METRÔRIO. Disponível em: https://www.metrorio.com.br/Novidades/PalcoCarioca. Acesso em: 16 nov. 2017.

MORLEY, David. For a Materialist, Non-Media-Centric Media Studies. Television \& New Media, v. 10, n. 1, p. 114-116, 2009. https://doi.org/10.1177/1527476408327173.

MÚSICOS são agredidos por seguranças do metrô. O Dia, Rio de Janeiro, 21 dez. 2015. Disponível em: https://odia.ig.com.br/noticia/rio-de-janeiro/2015-12-21/ musicos-sao-agredidos-por-segurancas-do-metro.html. Acesso em: 14 ago. 2017.

NITAHARA, Akemi. Lei do Artista de Rua precise de mais divulgação, diz Amir Haddad. Empresa Brasileira de Comunicação (EBC), Brasília, 5 jun. 2016. Disponível em: $\quad$ http://www.ebc.com.br/cultura/2015/06/lei-do-artista-de-rua-do-rioprecisa-de-mais-divulgacao-diz-amir-haddad. Acesso em: 16 nov. 2017.

OLIVEIRA, Nelma Gusmão de. O poder dos jogos e os jogos de poder. Rio de Janeiro: Editora UFRJ, 2015.

PICKER, John M. Victorian Soundscapes. Nova York: Oxford Univesity Press, 2003.

PROJETO de lei que autoriza músicos em trens e metrô é discutido na Alerj. G1, Rio de Janeiro, 6 out. 2015. Disponível em: http://g1.globo.com/rio-de-janeiro/ noticia/2015/10/projeto-de-lei-que-autoriza-musicos-em-trens-e-metro-ediscutido-na-alerj.html. Acesso em: 14 ago. 2017.

REIA, Jhessica. We Are not a Protest: Street Performance and/as Public Art in the City of Rio De Janeiro. In: IANNELLI, Laura; MUSARÒ, Pierluigi (Org.). Performative Citizenship. Fano: Mimesis International, p. 133-150, 2017 a.

. Os palcos efêmeros da cidade. ECO-PóS, Rio de Janeiro, v. 20, n. 3, p. 81-95, 2017b. http://dx.doi.org/10.29146/eco-pos.v20i3.12409. 
. A lei no bolso. In: FERNANDES, Cíntia S.; HERSCHMANN, Micael (orgs.) Cidades Musicais: Comunicação, Territorialidade e Política. Porto Alegre: Ed. Sulina, 2018.

REIS, Ana Carla. Cidades Criativas. São Paulo: SESI-SP, 2012.

RIGUETTI, Richard. Entrevista realizada por Micael Herschmann e Cíntia Sanmartin Fernandes, em 6 de julho de 2015.

RODRIGUES, Cristiane. Artistas de rua faturam até R\$ 2 mil por dia no Boulevard Olímpico. G1, Rio de Janeiro, 6 ago. 2016. Disponível em: http://g1.globo.com/ rio-de-janeiro/olimpiadas/rio2016/noticia/2016/08/artistas-de-ruas-faturamate-r-2-mil-por-dia-no-boulevard-olimpico.html. Acesso em: 15 nov. 2017.

ROLNIK, Raquel; FERNANDES, Ana (orgs.). Cidades. Rio de Janeiro: Funarte, 2016.

SANTA BÁRBARA, Reimont Luiz Otoni. Entrevista realizada por Micael Herschmann e Cíntia Sanmartin Fernandes em 2 de maio de 2017.

SANTAELLA, Lucia (org.). Cidades Inteligentes. São Paulo: Estação das Letras e Cores, 2016.

SENNETT, Richard. The Fall of the Public Man. Londres: Penguin Books, 2002.

TELLES, Vera. Ilegalismos populares e relações de poder nas tramas da cidade. In: Robert Cabanes e outros. Saídas de Emergência. São Paulo: Boitempo, p. 155167, 2011.

UNESCO CREATIVE CITIES NETWORK. Disponível em: http://en.unesco.org/creativecities/home. Acesso em: 3 mar. 2017.

URRY, John. City Life and the Senses. In: Gary Bridge and Sophie Watson (eds.). Companion to the City. Londres: Wiley Online Library, p. 388-397, 2008. https:// doi.org/10.1002/9780470693414.ch33.

VIVANT, Elza. O que é uma cidade criativa. São Paulo: Ed. SENAC, 2012.

Recebido em: 06/05/2018

Aceito em: 09/05/2018

Dados dos autores:

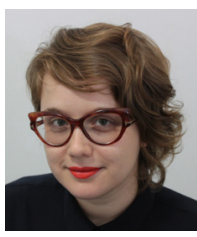

Jhessica Reia|jheleiosa@gmail.com

Centro de Tecnologia e Sociedade da Fundação Getulio Vargas DIREITO RIO (CTS-FGV)

Doutora em Comunicação pela UFRJ e pesquisadora do Centro de Tecnologia e Sociedade da Fundação

Getulio Vargas DIREITO RIO (CTS-FGV).

Endereço da autora:

Centro de Tecnologia e Sociedade da Fundação Getulio Vargas DIREITO RIO (CTS-FGV)

Praia de Botafogo, $190-13^{\circ}$ andar

22.250-900 - Rio de Janeiro/RJ 


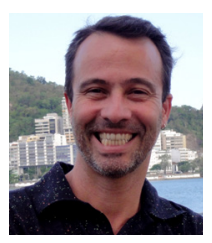

Micael Herschmann | micaelmh@globo.com

Universidade Federal do Rio de Janeiro (PPGCOM-UFRJ).

Doutor em Comunicação pela UFRJ e professor do Programa de Pós-Graduação em Comunicação da

Universidade Federal do Rio de Janeiro (PPGCOM-UFRJ).

Endereço do autor:

Secretaria de Ensino de Pós-Graduação da Escola de Comunicação da UFRJ

Av. Pasteur, n० 250 - fds

Bairro Urca

22.290-240 - Rio de Janeiro/RJ

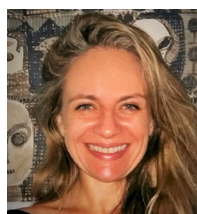

Cíntia Sanmartin Fernandes | cintia@lagoadaconceicao.com

Universidade Estadual do Rio de Janeiro (PPGCOM-UERJ).

Doutora em Sociologia Política pela UFSC e coordenadora do Programa de Pós-Graduação em

Comunicação da Universidade Estadual do Rio de Janeiro (PPGCOM-UERJ).

Endereço do autor:

Secretaria do PPGCOM-UERJ

Rua São Francisco Xavier, 524 - 10 andar, sala 10.121, bloco F, Pavilhão João Lyra Filho

Bairro Maracanã

20.550-900 - Rio de Janeiro/RJ

Nota explicativa: O artigo se baseia, em grande parte, na tese de doutorado de Jhessica Reia, desenvolvida entre 2013 e 2017 sob orientação de Micael Herschmann e Will Straw. A partir de uma reflexão da regulação e táticas de resistência da música de rua, esse artigo também traz contribuições de - e dialoga com - o trabalho de Micael Herschmann e Cintia Sanmartin Fernandes intitulado Música nas ruas do Rio de Janeiro (Ed. Intercom, 2014), referentes à publicações e projetos de pesquisa realizados em parcerias entre UFRJ e UERJ, dos quais todos os três autores vêm participando desde 2014.

Contribuições dos autores: Todos os autores fizeram contribuições substanciais para concepção, desenvolvimento, redação e revisão crítica do trabalho; e aprovação final da versão para publicação.

Este artigo é licenciado sob forma de uma licença Creative Commons Atribuição 4.0 Internacional (CC-BY). 